Article

\title{
Effect of Distribution Uniformity and Fertigation Volume on the Bio-Productivity of the Greenhouse Zucchini Crop
}

\author{
Juana I. Contreras ${ }^{1, * \mathbb{C}}$, Rafael Baeza ${ }^{1}$, Francisca Alonso ${ }^{1}$, Gema Cánovas ${ }^{1}$, Pedro Gavilán ${ }^{2}$ and \\ David Lozano ${ }^{2}$ \\ 1 Institute of Research and Training in Agriculture and Fishery (IFAPA), Junta of Andalucia, La Mojonera, \\ 04745 Almería, Spain; rafaelj.baeza@juntadeandalucia.es (R.B.); f.alonso@juntadeandalucia.es (F.A.); \\ gema.canovas@juntadeandalucia.es (G.C.) \\ 2 Institute of Research and Training in Agriculture and Fishery (IFAPA), Junta of Andalucia, Alameda del Obispo, \\ 14004 Córdoba, Spain; pedrod.gavilan@juntadeandalucia.es (P.G.); david.lozano@juntadeandalucia.es (D.L.) \\ * Correspondence: juanai.contreras@juntadeandalucia.es; Tel.: +34-950-156-453
}

Received: 9 July 2020; Accepted: 31 July 2020; Published: 3 August 2020

check for updates

\begin{abstract}
Greenhouse horticultural crops are characterized by high levels of efficiency and productivity of irrigation water and nutrients applied. However, these indices may be affected by poor distribution uniformity of fertigation (DU). Different previous prospective studies show that there is a significant percentage of facilities with a low level of DU. However, there is no precise relationship between DU and the efficiency and productivity of water and fertilizers. This relationship may be affected by different factors, especially by the irrigation dose. The objective of this work was to determine the effect of the distribution uniformity of fertigation and the fertigation volume (FV) on the bio productive parameters and efficiency of water and nutrient use of the zucchini crop. The trial was developed in a greenhouse located in La Mojonera (Almería), on sanded soil. The greenhouse was equipped with an automated fertigation installation. The experimental design was randomized complete blocks with six treatments and three repetitions. The established treatment was a combination of two factors: distribution uniformity and fertigation volume. Three levels of DU were established: 100\%, 75\% and $50 \%$ approximately and two levels of fertigation volume: FV100\% and FV70\%. Volume of water and nutrients applied, soil matric potential (SMP), yield, biomass and efficiency in the water and nutrients use were determined. The maximum efficiency in the use of water and nutrients was obtained with a DU of $100 \%$ or $75 \%$ and a fertigation volume of $\mathrm{FV} 70 \%$, but this fertigation volume reduced the bio-productive parameters of the crop such as yield. The maximum yield and biomass were obtained with the volume of fertigation of $100 \%$ (FV100\%), and with a DU of $100 \%$ or $75 \%$. DU50\% level reduced all bio-productive parameters, reducing yield by $45 \%$, as well as the water use efficiency (WUE) and nutrient efficiency with any level of fertigation.
\end{abstract}

Keywords: Cucurbita pepo L.; soil matric potential; ETc; yield; biomass; water use efficiency; nutrient use efficiency

\section{Introduction}

Agriculture is by far the main user of water in the world. Irrigated agriculture accounts for $70 \%$ of water withdrawals, which can rise to more than $90 \%$ in some regions. Around $20 \%$ of total water used globally is from groundwater sources (renewable or not), and this share is rising rapidly, particularly in dry areas [1]. Drip irrigation, also called trickle irrigation or micro-irrigation, is a localized irrigation method that slowly and frequently provides water directly to the plant root zone [2]. It is considered to be a low-cost water-delivery system. Due to limited water resources and environmental consequences 
of common irrigation systems, drip irrigation technology has received more attention and played an important role in agricultural production. Therefore, the use of drip irrigation systems is rapidly increasing around the world. Moreover, irrigation management also needs to be efficient in order to help reduce the environmental impact and to promote the sustainable use of resources $[3,4]$.

Greenhouse horticultural crops are characterized by high levels of efficiency and productivity of irrigation water and nutrients applied [5], and practically all farms have drip irrigation. However, these indices may be affected by poor distribution uniformity (DU) of fertigation. Different previous prospective studies show that there is a significant percentage of facilities with a low level of DU [6,7]. This low uniformity may be associated with different factors, such as water quality [8], terrain slope [9,10], production system [3], etc.

Some research has shown the importance of flow distribution uniformity on the growth, productivity and quality of different crops, such as cotton [11], maize [12] and onion [13], among others. However, other studies show that irrigation system uniformity does not have a significant influence on the yield of some crops [14-16]. In any case, the decrease in uniformity is associated with higher water consumption, since water is irrigated above the needs of the crop, to ensure that the most unfavorable points receive the necessary water. However, there is no precise relationship between DU and the efficiency and productivity of water and fertilizers in greenhouse horticultural crops. This relationship may be affected by different factors, especially by the irrigation dose [11].

There are numerous works that determine the water and nutrient needs of intensive horticultural crops. Most of the work carried out to determine water needs focuses on the predictive calculation of crop evapotranspiration (ETc) with average climate data or real-time data [17-19]; however, the different vegetative development obtained for the same crop depending on the variety and growth conditions has directed the most recent investigations towards the dynamic determination of $\mathrm{Kc}_{\mathrm{c}}$ in situ, by means of photo digitization systems that monitor the growth of the plant [20], as well as the use of soil moisture sensors that allow irrigation on demand [3].

Among the horticultural crops, zucchini squash (Cucurbita pepo L.) is an important plant in many countries for out of season greenhouse production; it is also an important commercial crop that has gained popularity for both open-field and protected cultivation in the Mediterranean region. Zucchini is normally grown in soil under greenhouse conditions using a drip-irrigation system during the spring-summer and the summer-fall seasons in order to respond to the high demand of this fresh product in both national and international markets. In Spain, zucchini is one of the main crops grown on the Mediterranean coast of Andalusia, Almeria being the main growing area with 7300 ha [21], but in comparison with other vegetables crops grown under protected cultivation, such as pepper, melon, and tomato, the studies on the effects of the dose of fertigation on this crop are scarcer, and there is a lack of information on the influence of the DU on fruit yield and water use efficiency (WUE) in the zucchini crop.

The objective of this work was to determine the effect of the distribution uniformity and the fertigation volume, as well as the possible interaction between both factors, on the bio productive parameters and the efficiency of water and nutrient use of zucchini grown in greenhouse soil culture.

\section{Materials and Methods}

\subsection{Experimental Site}

The experiment was conducted in a $1700 \mathrm{~m}^{2}$ polyethylene greenhouse (Parral greenhouse), which was without heating and naturally ventilated. Soil in the experimental greenhouse was gravel-sand mulched with loamy soil, the standard soil of intensive horticultural crops in the peninsular Southeast [22].

The experimental greenhouse was located at the Institute of Research and Training in Agriculture and Fisheries (IFAPA), located in La Mojonera City, Almería Province of Southeast Spain (longitude $2^{\circ} 41^{\prime} \mathrm{W}$, latitude $36^{\circ} 47^{\prime} \mathrm{N}$, elevation $160 \mathrm{~m}$ ), in this place is located one of the highest concentrations of 
greenhouses in the world. The climate is Mediterranean with a mild winter (mean monthly temperature of $12.9^{\circ} \mathrm{C}$ in winter) and a mean annual precipitation of $220 \mathrm{~mm}$.

\subsection{Experimental Design and Cropping Systems}

The experimental design used was a randomized complete block $2 \times 3$ factorial design with three replicates, resulting in the combination of the two factors studied in the six treatments tested. The greenhouse was divided into 18 experimental plots, in three blocks set out from east to west, with a passage in the north. Each experimental plot measured $23 \times 4 \mathrm{~m}$.

The factors studied were: distribution uniformity (DU) and fertigation volume (FV). Three levels of DU were established: $100 \%, 75 \%$ and 50\%, approximately (real: $98.8 \%, 74.1 \%, 49.3 \%$ ) and two levels of fertigation volume: $\mathrm{FV} 100 \%$ and $\mathrm{FV} 70 \%$.

DU levels were generated with drippers of the same or different flow rates placed in order in each irrigation line to obtain the desired levels (Figure 1). All drip emitters were pressure-compensating and no-draining (PCJ Dripper-Netafim ${ }^{\circledR}$ ). The number of emitters of each of the flows was established using the Monte-Carlo method. The total number of emitters per dripper pipeline was 44 , since the pipelines were $22 \mathrm{~m}$ and the distance between drippers was $0.5 \mathrm{~m}$. Each experimental plot was three pipelines spaced $1 \mathrm{~m}$, leaving a border to avoid interferences between plots.

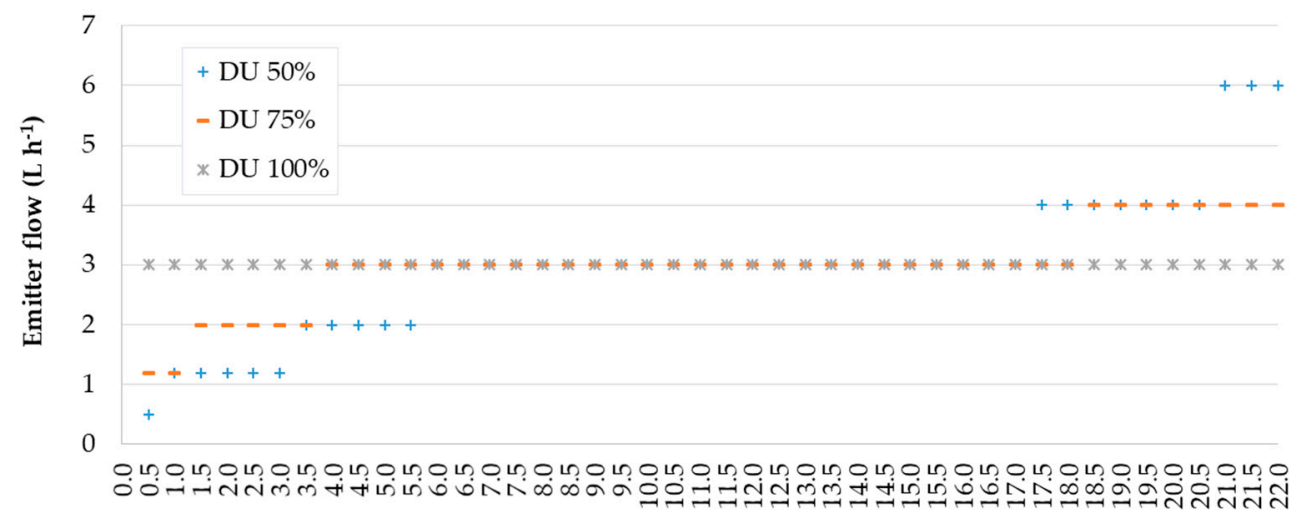

Distance of the emitter with respect to the insertion in the branch pipeline $(\mathrm{m})$

Figure 1. Diagram of the distribution of emitters and their flow rate in the drip pipeline for each of the uniformity distribution coefficient (DU) levels studied.

The uniformity distribution coefficient (DU) was estimated by accounting for all the issuers and using the classical methodology proposed by Keller and Karmeli [23], who proposed the following equation:

$$
\mathrm{DU}=(\mathrm{q} 25 \% / \mathrm{qm}) \times 100
$$

where:

$\mathrm{q} 25 \%$ average discharge of the $25 \%$ of the emitters with the lowest flow rate $\left(\mathrm{L} \mathrm{h}^{-1}\right)$;

$\mathrm{qm}=$ average discharge of all emitter tested $\left(\mathrm{L} \mathrm{h}^{-1}\right)$.

FV levels were established based on the ETc of the crop and the application of a nutrient solution recommended for the crop. A prescriptive-corrective method was used to determine the ETc. The ETc of the zucchini crop was previously calculated using the software PrHo v 2.0 (C) 2020 (Cajamar Experimental Station, Almería, Spain). This program determines the daily evapotranspiration (ETc, $\mathrm{L} \mathrm{m}^{-2} \mathrm{~d}^{-1}$ ) of the greenhouse crop using the Kc-ETo method [24]. The calculated ETc was corrected in real time based on the value of the soil matric potential. The objective was to maintain the soil matric potential between -15 and $-20 \mathrm{kPa}$ before the activation of the irrigation for the level of $\mathrm{FV} 100 \%$, 
potentially suitable for this crop under similar conditions of development [3]. The FV70\% level was obtained by reducing the timing by $30 \%$ in each irrigation with respect to FV $100 \%$. The irrigation frequency was the same in both levels and varied during the crop cycle depending on the needs. For each of the levels, the timing of irrigation was constant throughout the cycle (30 min in FV100\% and $21 \mathrm{~min}$ in $\mathrm{FV} 70 \%$ ).

The irrigation water and nutrient solutions used in this experiment are shown in Table 1 . The water used was desalinated seawater. The composition of the nutrient solution was constant during the crop cycle, and it was based on Camacho and Fernandez [25].

Table 1. Composition of irrigation water (Water) and fertigation solution (Solution F.).

\begin{tabular}{ccccccccccccc}
\hline & $\mathbf{p H}$ & $\mathbf{E C}$ & $\mathbf{H C O}_{3}{ }^{-}$ & $\mathbf{C l}^{-}$ & $\mathbf{S O}_{4}{ }^{2-}$ & $\mathbf{N O}_{3}{ }^{-}$ & $\mathbf{P}$ & $\mathbf{N H}_{4}{ }^{+}$ & $\mathbf{C a}^{2+}$ & $\mathbf{M g}^{2+}$ & $\mathbf{N a}^{+}$ & $\mathbf{K}^{+}$ \\
\hline Water & 7.69 & 0.48 & 2.00 & 2.23 & 0.21 & 0.08 & 0.00 & 0.00 & 0.72 & 0.41 & 2.48 & 0.20 \\
Solution F. & 6.00 & 2.49 & 0.50 & 2.23 & 2.27 & 12.0 & 1.50 & 0.00 & 4.50 & 1.50 & 2.48 & 6.50 \\
\hline
\end{tabular}

Zucchini plants (Cucurbita pepo L. cv. Victoria) were transplanted on 15 March 2018 with a plant density of 1 plants $\mathrm{m}^{-2}$, and the cycle ended on 22 June 2018 (spring cycle).

Regarding soil fertility, the greenhouse soil had a low cation exchange capacity (CEC, $6.83 \mathrm{meq} / 100 \mathrm{~g})$, low organic matter content (OM, 0.89\%), low nitrogen ( $0.065 \% \mathrm{~N}$ organic) and potassium $\left(\mathrm{K}, 310 \mathrm{mg} \mathrm{kg}^{-1}\right)$ level and a high phosphorus content $\left(\mathrm{P}, 56.5 \mathrm{mg} \mathrm{kg}^{-1}\right)$.

\subsection{Measurements}

- Soil matric potential (SMP, $\mathrm{kPa}$ ): the soil matric potential for each level of FV was measured using tensiometers during the entire crop cycle. Six soil moisture tensiometers-3 per level (Irrometer Co., inc. Riverside, CA, USA)—-were installed. The measurements were recorded every day before the irrigation (around 9.00 a.m.). Tensiometers were installed at $15 \mathrm{~cm}$ from the base of the plant and $15 \mathrm{~cm}$ deep, an area of great root representativeness. The installation of the tensiometers was carried out on March 30, 15 days after the transplant to ensure the installation in plants that had adequate development.

- Irrigation water and nutrients applied: the water applied $\left(\mathrm{L} \mathrm{m}^{-2}\right)$ was measured by installing three volumetric water meters (model M120 (Elster, Iberconta S.A., Guipúzcoa, Spain) for one level, which also checked and corroborated with the registration number of irrigations performed and the volume applied in each irrigation. The concentration of nutrients in the applied nutrient solution was analyzed in the laboratory weekly. The samples were collected at the outlet by the dropper, placing a carafe that collected the volume of fertigation applied weekly in each treatment. The EC $\left(\mathrm{dS} \mathrm{m}^{-1}\right), \mathrm{pH}$ and concentration of $\mathrm{NO}_{3}{ }^{-}, \mathrm{P}, \mathrm{K}^{+}, \mathrm{Ca}^{2+}$ and $\mathrm{Mg}^{2+}(\mathrm{mM})$ were determined.

- Yield: fruit production was evaluated according to the following parameters: marketable yield by categories and calibers, and unmarketable yield. The 1st Category was of superior quality: well-developed, well-formed zucchini with the stalk neatly cut, a maximum length of $3 \mathrm{~cm}$ and free from defects, with the exception of very slight superficial defects. The 2nd Category was of good quality: zucchini included a stalk of a maximum length of $3 \mathrm{~cm}$, but had a slight defect in shape, slight defects in coloration, slight skin defects and very slight defects due to diseases provided that they were not progressive and did not affect the flesh. The 1st Category was separated into calibers based on weight: Caliber 1 was fruits less than $225 \mathrm{~g}$, Caliber 2 was fruits between 225 and $450 \mathrm{~g}$ and Caliber 3 was fruits lager than $450 \mathrm{~g}$ (fresh fruit weight $\left(\mathrm{kg} \mathrm{m}^{-2}\right)$ and number of fruits (Fruits $\left.\mathrm{m}^{-2}\right)$ ). The fruits were manually harvested during the harvest period, controlling in all harvests the production of 44 plants (all plants of one whole pipeline) per plot, resulting in a total of 132 plants per level. The harvest period started on 15th April 2018 and ended on 15st June 2018, with a total of 26 harvests. 
- Shoot biomass: whole plants, excluding the roots, were harvested from each experimental plot (six plants per replication) throughout the experiment. For the levels in which there were plants that received nutrient solutions with different emitter flow rates (FV75 and FV50), plants corresponding to all the emitter flows were selected, and the weighted average was calculated. Samples were partitioned into fruits (generative), leaves and stems. Harvested ripe fruits throughout the cycle were randomly selected at every harvesting, collecting 20 fruits per experimental plot. Fresh samples were dried at $70{ }^{\circ} \mathrm{C}$ to constant weight and dry biomass (DB, $\mathrm{g} \mathrm{m}^{-2}$ ), and dry matter (DM, \%) was determined.

- Harvest index $\left(\mathrm{HI}, \mathrm{g} \mathrm{g}^{-1}\right)$ : the harvest index was determined as the ratio between generative dry biomass and total shoot dry biomass.

- Water and nutrient use efficiency: water and nutrient use efficiency can be calculated in many ways [26-30]. We defined the efficiencies the following way:

1. Water Use Efficiency (WUE, $\mathrm{kg} \mathrm{m}^{-3}$ ) calculated according to Food and Agriculture Organization (FAO) [31]; Ym/Wc where: $\mathrm{Ym}$ is fruit marketable yield $\left(\mathrm{kg} \mathrm{m}^{-2}\right)$ and $\mathrm{Wc}_{\mathrm{c}}$ is water applied $\left(\mathrm{m}^{3} \mathrm{~m}^{-2}\right)$.

2. Nitrogen Use Efficiency (NUE, $\left.\mathrm{kg} \mathrm{kg}^{-1}\right) ; \mathrm{Ym} / \mathrm{Nc}$ where: $\mathrm{Ym}$ is fruit marketable yield $\left(\mathrm{kg} \mathrm{m}^{-2}\right)$ and $\mathrm{Nc}$ is nitrogen applied $\left(\mathrm{kg} \mathrm{m}^{-2}\right)$.

3. Phosphorus Use Efficiency (PUE, $\mathrm{kg} \mathrm{kg}^{-1}$ ); $\mathrm{Ym} / \mathrm{Pc}$ where: $\mathrm{Ym}$ is fruit marketable yield $\left(\mathrm{kg} \mathrm{m}^{-2}\right)$ and $\mathrm{Pc}$ is phosphorus applied $\left(\mathrm{kg} \mathrm{m}^{-2}\right)$.

4. Potassium Use Efficiency (KUE, $\mathrm{kg} \mathrm{kg}^{-1}$ ); $\mathrm{Ym} / \mathrm{Kc}$ where: $\mathrm{Ym}$ is fruit marketable yield $\left(\mathrm{kg} \mathrm{m}^{-2}\right)$ and $\mathrm{Kc}$ is potassium applied $\left(\mathrm{kg} \mathrm{m}^{-2}\right)$.

5. Calcium Use Efficiency (CaUE, $\mathrm{kg} \mathrm{kg}^{-1}$ ); $\mathrm{Ym} / \mathrm{Cac}$ where: $\mathrm{Ym}$ is fruit marketable yield $\left(\mathrm{kg} \mathrm{m}^{-2}\right)$ and Cac is calcium applied $\left(\mathrm{kg} \mathrm{m}^{-2}\right)$.

6. Magnesium Use Efficiency (MgUE, $\left.\mathrm{kg} \mathrm{kg}^{-1}\right)$; $\mathrm{Ym} / \mathrm{Mgc}$ where: $\mathrm{Ym}$ is fruit marketable yield $\left(\mathrm{kg} \mathrm{m}^{-2}\right)$ and $\mathrm{Mgc}$ is magnesium applied $\left(\mathrm{kg} \mathrm{m}^{-2}\right)$.

\subsection{Statistical Analysis}

Data were analyzed using analysis of variance (ANOVA) as a $2 \times 3$ factorial randomized complete block design, with three replications. A multifactor ANOVA was also performed to identify the significant factors (DU and FV) and interactions between the factors. Percentage data were transformed with the arcsine square root transformation to obtain a normal distribution. For each analysis, when ANOVA was significant, statistically significant differences between means were identified using an LSD (least significance difference) test $(p \leq 0.05)$. Statistical analyses were performed with Statgraphics 18 (2020 Statgraphics Technologies, Inc., The Plains, VA, USA).

\section{Results}

\subsection{Soil Matric Potential (SMP)}

The installation of the tensiometers was carried out on 23 March, 8 days after the transplant, to ensure the installation in plants that had an adequate development. Tensiometers were installed at $15 \mathrm{~cm}$ deep below the gravel-sand layer and $15 \mathrm{~cm}$ of the plant.

The values of soil matric potential recorded in the studied PV levels are shown in Figure 2. The values that appear in the figure were recorded before irrigation; around 9:00 a.m. every day.

The soil matric potential at the start of the cycle crop (10-19 DAT) was similar for the two treatments and close to $-20 \mathrm{kPa}$. Although, already in this period, it can be seen how the $\mathrm{FV} 70 \%$ treatment showed a matrix potential of the soil farthest from zero, with a lower level of humidity in this treatment. In this period, the volume applied in the FV100\% treatment was that established by the estimated ETc. From that period on (from day 20 to 99 DDT), the applied volume was corrected with the tensiometer readings, to place the soil matric potential between -15 and $-20 \mathrm{kPa}$ for the FV100\% 
treatment. The FV70\% treatment received 30\% less fertigation volume and this caused the matric potential of the soil to be between -25 and -35 , with greater fluctuation during the cultivation cycle. Throughout the cycle, the soil matric potential of the FR100 treatment was closer to zero than that of the FR70\% treatment, showing the highest level of soil moisture present in this treatment.

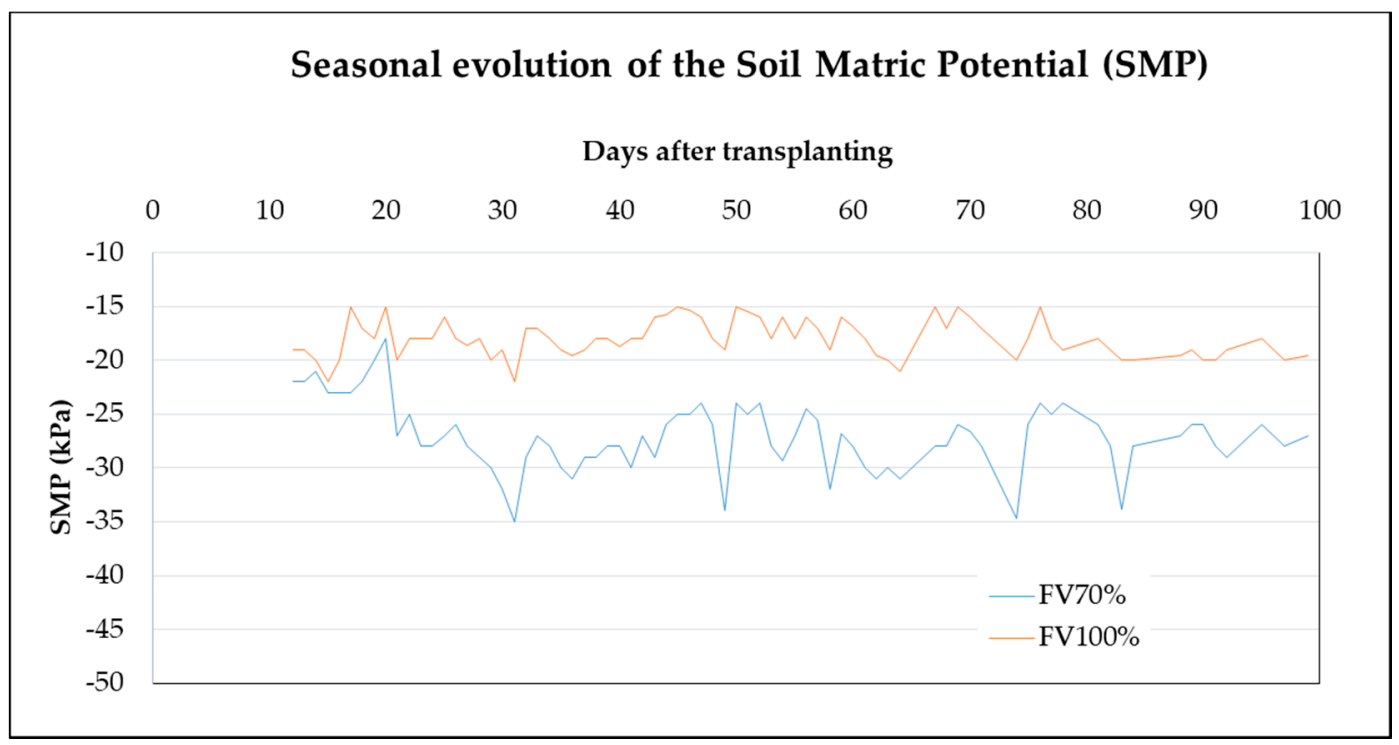

Figure 2. Seasonal evolution of the soil matric potential (SMP) measured at 9.00 a.m., before the irrigation. Mean of 3 values for each level of fertigation volume (FV) (FV70\% and FV100\%). Measurements taken at $15 \mathrm{~cm}$ deep below the gravel-sand layer and $15 \mathrm{~cm}$ of the plant.

\subsection{Irrigation Water Applied and Nutrients}

The evolution of the water applied during the culture cycle in the FV100\% and FV70\% treatments is shown in Figure 3, as well as the ETc estimated by software PrHo v 2.0 (C) 2020 for the cultivation cycle. The FV100\% treatment applied a total of $376 \mathrm{~L} \mathrm{~m}^{-2}$, applying the FV70\% treatment $262 \mathrm{~L} \mathrm{~m}^{-2}$ (30\% less). The estimated ETc by software PrHo v 2.0 (C) 2020 for the total cultivation cycle was $272 \mathrm{~L} \mathrm{~m}^{-2}$.

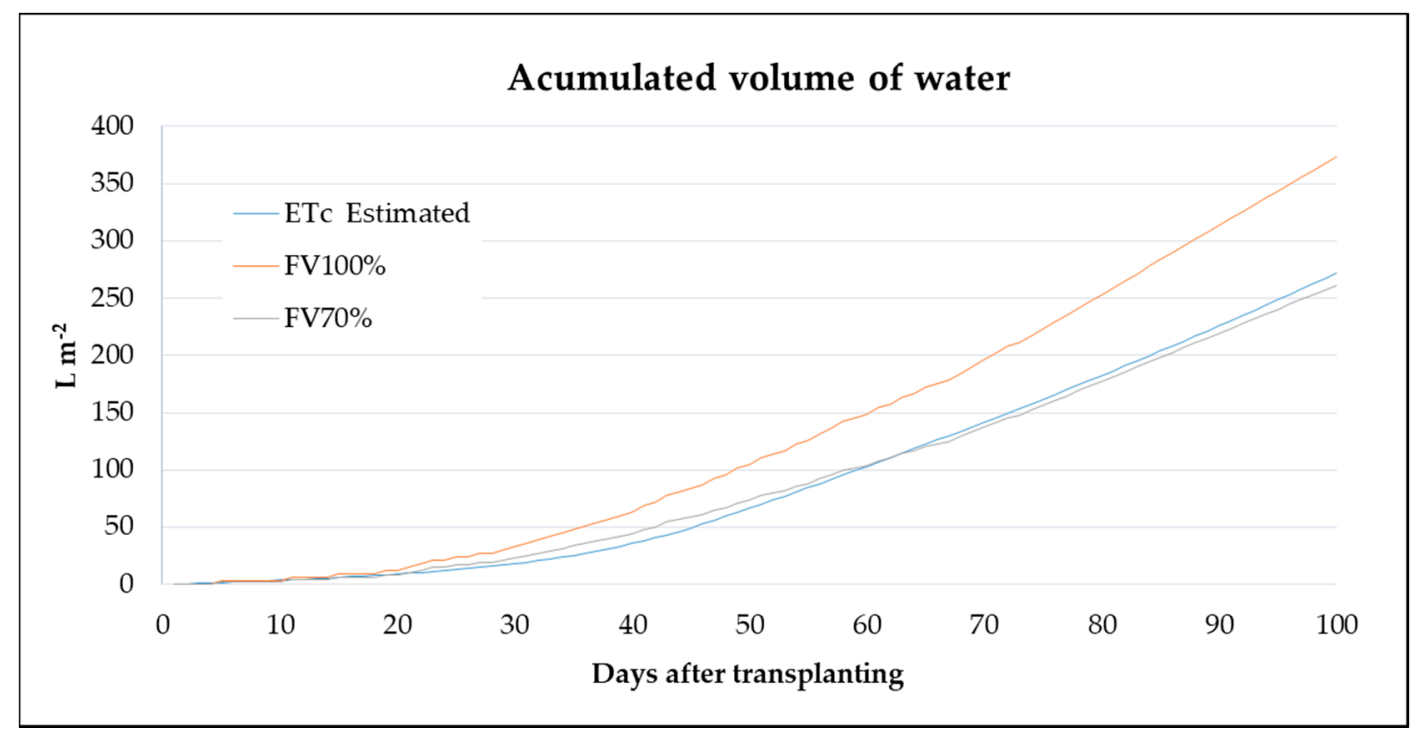

Figure 3. Accumulated volume of water applied in the FV $100 \% \%$ and FV70\% treatments during the cultivation cycle and estimated ETc by software PrHo v 2.0 (C) 2020 for the cultivation cycle. 
The nutrient solution was maintained constant throughout the crop cycle, thus the supply of nutrients was related to the water supply. In the FV100\% treatment, a total of $62.93 \mathrm{~g} \mathrm{~m}^{-2}$ of N, $17.42 \mathrm{~g} \mathrm{~m}^{-2}$ of $\mathrm{P}, 94.96 \mathrm{~g} \mathrm{~m}^{-2}$ of $\mathrm{K}, 67.43 \mathrm{~g} \mathrm{~m}^{-2}$ of $\mathrm{Ca}$ and $13.65 \mathrm{~g} \mathrm{~m}^{-2}$ of $\mathrm{Mg}$ were applied. In the FV70\% treatment, $30 \%$ less were applied $\left(44.05 \mathrm{~g} \mathrm{~m}^{-2}\right.$ of $\mathrm{N}, 12.19 \mathrm{~g} \mathrm{~m}^{-2}$ of $\mathrm{P}, 66.47 \mathrm{~g} \mathrm{~m}^{-2}$ of $\mathrm{K}, 47.20 \mathrm{~g} \mathrm{~m}^{-2}$ of $\mathrm{Ca}$ and $9.56 \mathrm{~g} \mathrm{~m}^{-2}$ of $\mathrm{Mg}$ ).

The water applied to maintain the soil matric potential between -15 and $-20 \mathrm{kPa}(\mathrm{FV} 100 \%)$ was almost 30\% higher than the ETc estimated by software PrHo v 2.0 (C) 2020 for the cultivation cycle. The FV70\% treatment approached the estimated ETc.

\subsection{Yield}

The two factors studied (DU and FV) affected zucchini yield (Table 2).

\section{- $\quad$ DU Effect}

The total marketable yield was affected by the DU level studied. DU $75 \%$ and DU $100 \%$ levels showed the highest marketable yield (11.01 and $11.54 \mathrm{~kg} \mathrm{~m}^{-2}$, respectively) without significant differences between them. The DU 50\% level reduced the marketable yield between $44 \%-45 \%$ with respect to DU $75 \%$ and DU $100 \%$ levels. Unmarketable yield was also significantly affected by UD, with UD 50\% having the lowest yield and number of fruits. In any case, unmarketable yield represented a very small percentage $(2.2 \%, 4.2 \%$ and $1.9 \%$ for DU100, DU75 and DU50, respectively) with respect to total production.

When analyzing the yield by category, it was observed that almost all of the yield was Category 1 in all the levels studied, representing between $96 \%$ and $98 \%$ according to the DU level (Table 2).

With regard to the sizes, the two levels of fertigation studied showed a similar percentage of Caliber 2 fruits (between 37\% and 39\% depending on the level), showing significant differences in the percentage of Caliber 1 and Caliber 3 fruits. DU100\% and DU75\% levels presented a higher percentage of Caliber 3 fruits than the DU50\% level, and the DU50\% level presented a higher percentage of smaller fruits (Caliber 1) than the DU75\% and DU100\% levels (Figure 4).

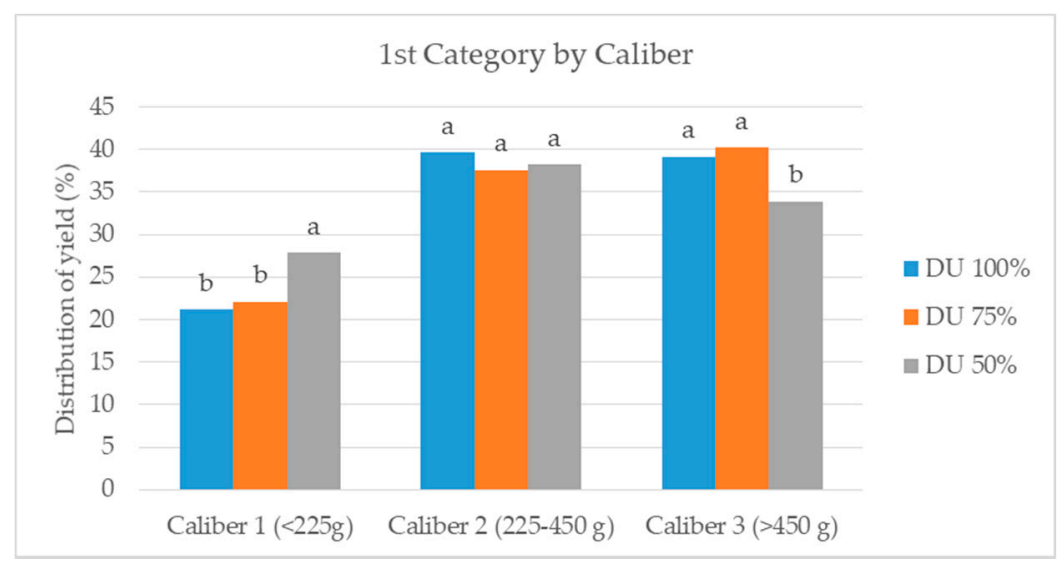

Figure 4. Distribution of 1st Category by Caliber of the yield. Columns marked with different lower case letters denote significant differences between DU levels by Caliber. ${ }^{*}$ significance for $p \leq 0.05$; ns, no significance. Different letters describe significant differences between levels of DU for calibers. 
Table 2. Marketable yield by categories and calibers, and unmarketable zucchini yield. Fresh fruit weight $\left(\mathrm{kg} \mathrm{m}^{-2}\right)$ and and number of fruits (Fruits $\mathrm{m}^{-2}$ ).

\begin{tabular}{|c|c|c|c|c|c|c|c|c|c|c|c|c|c|c|}
\hline & \multicolumn{10}{|c|}{ Marketable by Category } & \multirow{4}{*}{\multicolumn{2}{|c|}{$\begin{array}{l}\text { Total Marketable } \\
\text { 1st + 2nd Category }\end{array}$}} & \multicolumn{2}{|c|}{ Unmarketable } \\
\hline & \multicolumn{8}{|c|}{ 1st Category } & \multicolumn{2}{|c|}{ 2nd Category } & & & & \\
\hline & \multicolumn{6}{|c|}{ 1st Category by Caliber } & \multirow{2}{*}{\multicolumn{2}{|c|}{ Total }} & \multirow{2}{*}{\multicolumn{2}{|c|}{ Total }} & & & & \\
\hline & \multicolumn{2}{|c|}{ Caliber $1(<225 g)$} & \multicolumn{2}{|c|}{ Caliber $2(225-450 \mathrm{~g})$} & \multicolumn{2}{|c|}{ Caliber $3(>450 \mathrm{~g})$} & & & & & & & & \\
\hline DU & * & * & * & * & * & * & * & * & * & * & * & * & * & * \\
\hline 100 & $13.4 \mathrm{a}$ & $2.39 \mathrm{a}$ & $12.1 \mathrm{a}$ & $4.47 \mathrm{a}$ & $7.3 \mathrm{a}$ & $4.41 \mathrm{a}$ & $32.9 \mathrm{a}$ & $11.27 \mathrm{a}$ & $2.4 \mathrm{ab}$ & $0.26 \mathrm{ab}$ & $35.3 \mathrm{a}$ & $11.54 \mathrm{a}$ & $2.3 \mathrm{a}$ & $0.26 \mathrm{~b}$ \\
\hline 75 & $13.1 \mathrm{a}$ & $2.33 \mathrm{a}$ & $11.3 \mathrm{~b}$ & $3.96 \mathrm{~b}$ & $6.3 a$ & $4.24 \mathrm{a}$ & $30.7 \mathrm{~b}$ & $10.54 a$ & $3.0 \mathrm{a}$ & $0.47 a$ & $33.7 \mathrm{a}$ & $11.01 \mathrm{a}$ & $2.6 \mathrm{a}$ & $0.48 \mathrm{a}$ \\
\hline 50 & $9.1 \mathrm{~b}$ & $1.72 \mathrm{~b}$ & $6.9 \mathrm{c}$ & $2.36 \mathrm{c}$ & $3.5 \mathrm{~b}$ & $2.09 \mathrm{~b}$ & $19.6 \mathrm{c}$ & $6.17 \mathrm{~b}$ & $1.6 \mathrm{~b}$ & $0.16 \mathrm{~b}$ & $21.2 \mathrm{~b}$ & $6.35 \mathrm{~b}$ & $0.7 \mathrm{~b}$ & $0.12 \mathrm{c}$ \\
\hline 100 & $12.6 \mathrm{a}$ & $2.25 a$ & $10.8 \mathrm{a}$ & $3.86 a$ & $6.3 \mathrm{a}$ & $4.13 \mathrm{a}$ & $29.7 \mathrm{a}$ & $10.25 \mathrm{a}$ & $2.5 \mathrm{a}$ & $0.32 \mathrm{a}$ & $32.1 \mathrm{a}$ & $10.57 \mathrm{a}$ & $1.2 \mathrm{~b}$ & $0.20 \mathrm{~b}$ \\
\hline 70 & $11.2 \mathrm{a}$ & $2.04 \mathrm{a}$ & $9.4 \mathrm{~b}$ & $3.33 \mathrm{~b}$ & $5.1 \mathrm{~b}$ & $3.04 \mathrm{~b}$ & $25.8 \mathrm{~b}$ & $8.42 \mathrm{~b}$ & $2.2 \mathrm{a}$ & $0.28 \mathrm{a}$ & $28.0 \mathrm{~b}$ & $8.70 \mathrm{~b}$ & $2.5 \mathrm{a}$ & $0.38 \mathrm{a}$ \\
\hline Interaction (DUxFV) & ns & $\mathrm{ns}$ & $*$ & ns & ns & $\mathrm{ns}$ & ns & $\mathrm{ns}$ & ns & ns & $*$ & ns & ns & ns \\
\hline
\end{tabular}

* significance for $p \leq 0.05$; ns, no significance. Different letters describe significant differences between groups of columns. 


\section{- $\quad$ FV Effect}

The FV factor significantly affected the yield of zucchini, reducing the total marketable yield by $18 \%$ (from 10.57 to $8.70 \mathrm{~kg} \mathrm{~m}^{-2}$ ) with the application of the FV70\% level. The reduction also registered in the number of fruits of total marketable yield for the DU70\% level stood at $13 \%$. Unmarketable yield represented a very low percentage with respect to the total yield at the two levels studied $(1.9 \%$ to $4.1 \%$ depending on level). The FV100\% level presented a lower unmarketable yield and number of fruits.

By analyzing yield by category, we found that almost all of the yield was Category 1 at the two levels studied, representing a $97 \%$ in both levels.

Regarding the caliber, the levels of fertigation showed significant differences in Caliber 2 and Caliber 3. FV100\% presented a higher yield and number of fruits for Caliber 2 and Caliber 3.

- Interaction Factors

In the yield parameters studied, there was only interaction between factors in the number of Caliber 2 fruits and in the number of total marketable fruits (Table 2). Figure 5 shows the interaction between UD and FV for the two parameters.

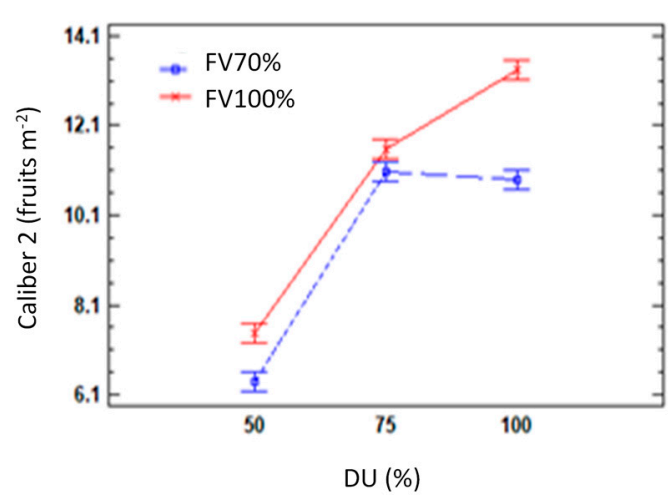

(a)

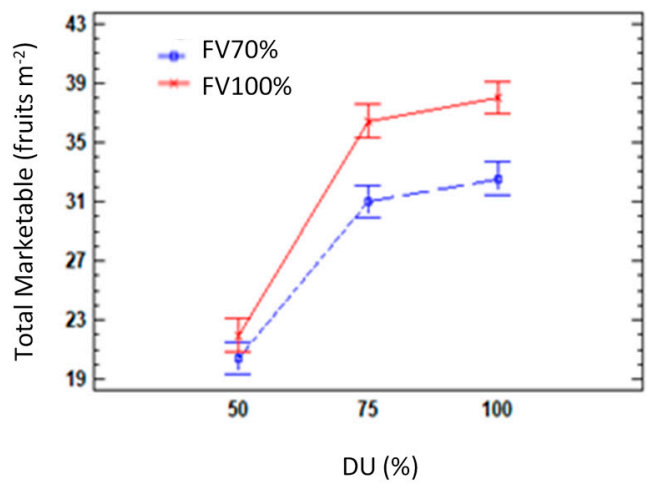

(b)

Figure 5. Interaction between DU and FV for number of fruits of Caliber 2 (a) and total marketable number of fruits (b). Averages and intervals LSD (least significance difference) 95\%.

In the case of the number of fruits of Caliber 2, the UD100\% FV100\% treatment presented the highest number of fruits of this caliber, showing that when a $100 \%$ fertigation was applied (FV100\%), there was an increase in the number of fruits with increased uniformity. However, when a fertigation of $75 \%(\mathrm{FV} 75 \%)$ was applied, there was only an increase in the number of fruits when it increased from $50 \%$ uniformity to $75 \%$, showing no significant differences when increasing from $75 \%$ to $100 \%$ (Figure 5a).

In the total of marketable fruits, UD75\% FV100\% and UD100\% FV100\% treatments presented the greatest number of marketable fruits. When a distribution uniformity of 50\% (UD50\%) was applied, there were no significant differences between the fertigation levels applied, and the lowest values of the number of marketable fruits were obtained (Figure 5b).

\subsection{Shoot Biomass}

The two factors studied (DU and FV) affected zucchini shoot biomass (Table 3). 
Table 3. Vegetative, generative and total shoot biomass and harvest index (HI). Dry Biomass (DB) in $g$ $\mathrm{m}^{-2}$ and Dry Matter (DM) in \%.

\begin{tabular}{|c|c|c|c|c|c|c|c|c|c|}
\hline & \multicolumn{4}{|c|}{ Vegetative Shoot Biomass } & \multirow{2}{*}{\multicolumn{2}{|c|}{$\begin{array}{c}\begin{array}{c}\text { Generative } \\
\text { Shoot Biomass }\end{array} \\
\text { Fruits } \\
\end{array}$}} & \multicolumn{2}{|c|}{$\begin{array}{c}\text { Total Shoot } \\
\text { Biomass }\end{array}$} & \multirow[t]{3}{*}{ HI } \\
\hline & \multicolumn{2}{|c|}{ Leaves } & \multicolumn{2}{|c|}{ Stems } & & & & & \\
\hline & DB & DM & DB & DM & DB & DM & DB & DM & \\
\hline & $\mathrm{g} \mathrm{m}^{-2}$ & $\%$ & $\mathrm{~g} \mathrm{~m}^{-2}$ & $\%$ & $\mathrm{~g} \mathrm{~m}^{-2}$ & $\%$ & $\mathrm{~g} \mathrm{~m}^{-2}$ & $\%$ & $\mathrm{~g} \mathrm{~g}^{-1}$ \\
\hline DU & * & ns & * & ns & * & ns & * & ns & * \\
\hline 100 & $783 a$ & $10.93 a$ & $111 \mathrm{a}$ & $10.52 a$ & $584 a$ & $4.96 a$ & $1478 \mathrm{a}$ & $7.39 a$ & $0.40 \mathrm{a}$ \\
\hline 75 & $686 b$ & $10.70 \mathrm{a}$ & $102 \mathrm{ab}$ & $10.50 \mathrm{a}$ & $553 a$ & $4.82 \mathrm{a}$ & $1314 a$ & $7.11 \mathrm{a}$ & $0.41 \mathrm{a}$ \\
\hline 50 & $606 c$ & $10.47 \mathrm{a}$ & $92 b$ & $10.29 \mathrm{a}$ & $303 b$ & $4.70 \mathrm{a}$ & $1001 b$ & $7.62 \mathrm{a}$ & $0.30 \mathrm{~b}$ \\
\hline FV & ns & $*$ & ns & ns & ns & * & ns & * & ns \\
\hline 100 & $711 \mathrm{a}$ & $9.91 \mathrm{~b}$ & $108 \mathrm{a}$ & $10.50 \mathrm{a}$ & $505 a$ & $4.67 \mathrm{~b}$ & $1324 a$ & $6.90 \mathrm{~b}$ & 0.38 \\
\hline 70 & $672 a$ & $11.49 \mathrm{a}$ & $960 a$ & $10.38 \mathrm{a}$ & $454 \mathrm{a}$ & $4.99 \mathrm{a}$ & $1222 \mathrm{a}$ & $7.77 a$ & 0.37 \\
\hline Interaction (DUxFV) & ns & ns & ns & ns & ns & ns & ns & ns & ns \\
\hline
\end{tabular}

${ }^{*}$ significance for $p \leq 0.05$; ns, no significance. Different letters describe significant differences between groups of columns.

\section{- $\quad$ DU Effect}

The DU level significantly affected the dry biomass of leaves, stems, fruits and total shoots. The harvest index (HI) was also significantly affected by the DU level. However, the DU level did not affect the dry matter of any of the vegetative organs (leaf and stem), the generative part (fruits)or the percentage of dry matter of the total shoots (Table 3). Decreasing uniformity to $50 \%$ significantly reduced vegetative and generative shoot biomass. In addition, the dry biomass of leaves decreased significantly linearly with the decrease in uniformity, also showing significant differences when reducing uniformity to $75 \%$. The harvest index was drastically reduced when the distribution uniformity decreased to $50 \%$, reducing the 0.40 or 0.41 obtained in DU100 and DU75, respectively, to 0.30 .

\section{- $\quad$ FV Effect}

The effect on the shoot biomass was different from that recorded when the DU level varied. The FV level significantly affected the dry matter of leaves, fruits and total shoots (Table 3), also affecting fresh matter (data not shown) but not dry biomass or HI. The reduction in the fertigation volume by $30 \%$ $(\mathrm{FV} 70 \%)$ produced a decrease in the percentage of dry matter of leaves, fruits and shoots.

There was no interaction between the factors in any of the biomass parameters studied.

\subsection{Water and Nutrient Use Efficiency}

The two factors studied (DU and FV) affected water and nutrient use efficiency by zucchini crops (Table 4).

\section{- $\quad$ DU Effect}

WUE and the efficiency of use of all nutrients (NUE, PUE, KUE, CaUE and MgUE) was significantly reduced by decreasing uniformity to $50 \%$ (DU50\%); however, no significant effect was found by reducing uniformity to $75 \%$ (Table 4 ).

\section{- $\quad$ FV Effect}

The reduction in the fertigation volume to 70\% (FV70) showed a significant increase in the efficiency of use of water and nutrients by $18 \%$ (for example, from 28 to $33 \mathrm{~kg} \mathrm{~m}^{-3}$ ) (Table 4).

There was no interaction between the factors in any of the biomass parameters studied. 
Table 4. Water use efficiency: WUE (expressed in $\mathrm{kg}$ of commercial fruit per $\mathrm{m}^{3}$ of water applied) and nutrient use efficiency, NUE: Nitrogen use efficiency, PUE: Phosphorus use efficiency; KUE: Potassium use efficiency, CaUE: Calcium use efficiency, MgUE: Magnesium use efficiency (expressed in $\mathrm{kg}$ of commercial fruit per kg nutrient applied).

\begin{tabular}{|c|c|c|c|c|c|c|c|}
\hline & & WUE & NUE & PUE & KUE & CaUE & MgUE \\
\hline \multirow[t]{4}{*}{ DU } & & * & * & * & * & * & * \\
\hline & 100 & $36.75 a$ & $218.78 \mathrm{a}$ & $790.44 a$ & $144.99 \mathrm{a}$ & $204.19 \mathrm{a}$ & $1008.39 a$ \\
\hline & 75 & $34.93 a$ & $207.97 a$ & 751.38a & $137.82 \mathrm{a}$ & 194.10a & $958.55 a$ \\
\hline & 50 & $20.43 b$ & $121.62 b$ & $439.43 b$ & $80.60 b$ & $113.52 b$ & $560.59 b$ \\
\hline \multirow[t]{3}{*}{ FV } & & * & * & * & * & * & * \\
\hline & 100 & $28.22 b$ & $168 b$ & $606.99 b$ & $111.34 b$ & $156.80 \mathrm{~b}$ & $774.36 b$ \\
\hline & 70 & $33.19 a$ & $197.58 \mathrm{a}$ & 713.84a & $130.941 a$ & $184.40 \mathrm{a}$ & $910.66 a$ \\
\hline Interac & UxFV) & ns & ns & ns & ns & ns & ns \\
\hline
\end{tabular}

* significance for $p \leq 0.05$; ns, no significance. Different letters describe significant differences between groups of columns.

\section{Discussion}

\subsection{DU Effect}

The large reduction in production (between $44 \%$ and $45 \%$ reduction compared to DU75 and DU100, respectively) observed with the decrease in irrigation uniformity to $50 \%$ shows the importance of the effect of a very sharp reduction in the DU on the productivity of the zucchini crop grown in the greenhouse, regardless of the fertigation volume studied (FV100 and FV70). However, a UD of 75\% showed no effect on crop production. These results are in line with those obtained by Wang et al. [32] that recommended the objective drip irrigation uniformity of UD $=75 \%$ for a higher cotton yield, while maintaining a lower installation cost in the arid region. To perform this recommended method, they determined the optimal drip system uniformity for cotton using a two-dimensional soil-water transport and crop growth coupling model that were calibrated and validated by soil-water dynamics, crop growth indices and cotton yield obtained from mulched drip irrigation field experiments in an arid region of Xinjiang Uygur Autonomous Region, China. The results were also similar to those obtained by Guan et al. [11] when weather conditions were favorable for cotton crop growth. They found that the low system uniformity treatment (DU 65\%) produced a significantly lower lint yield than the medium (DU 80\%) and high (DU 95\%) uniformity treatments at the full irrigation level, and they concluded that the value of around $80 \%$ could be used as the target uniformity of drip irrigation systems. However, Zhao et al. [16] concluded that growth, yield and quality of Chinese cabbage observed when the drip irrigation uniformity ranged from $57 \%$ to $96 \%$ were similar; in fact, the uniformity of drip irrigation had an insignificant effect on growth, yield and quality of Chinese cabbage at a significance level of $5 \%$. In this line, Wang et al. [12], in spring maize crop, obtained that the effect of drip uniformity (DU of $59 \%, 80 \%$, and $97 \%$ ) on yield was not significant. These results denote the importance of determining the effect of the UD for each crop and each production system.

DU50\% not only affected the production of the zucchini crop, it also reduced vegetative growth, coinciding with that obtained by other authors in other crops [11,12,32]. It also modified the HI, significantly reducing it from 0.40 to $0.30 \mathrm{~g} \mathrm{~g}^{-1}$, as well as the WUE and efficiency of use of nutrients that were reduced by around $30 \%$.

Regarding the interaction between factors (DU and FV), we only found an interaction in the number of fruits that was greater in the treatments with the higher fertigation dose and higher uniformities (DU75\% FV100\% and DU100\% FV100\% treatments). In the other growth and efficiency parameters, no interaction was obtained between the factors studied. These results are in line with those obtained by Guan et al. [11] for the cotton crop, who found that the influence of system uniformity on lint yield was related to the level of irrigation and the favorability of weather conditions for obtaining the potential yield. They determined that when the weather conditions (e.g., temperature) were 
favorable for crop growth, the low system uniformity treatment produced a significantly lower lint yield than the medium and high uniformity treatments at the full irrigation level. The interactive effects of system uniformity and irrigation level on crop growth and lint quality were insignificant.

\subsection{FV Effect}

The greater availability of water and nutrients obtained at the FV100 level (the level at which the SMP threshold was closest to 0 : between -15 and $-20 \mathrm{kPa}$ ) increased the production and number of zucchini fruits as a consequence of a greater number of fruits of a greater caliber. The results obtained are in line with those obtained in previous works [3] where a linear relationship was obtained between the marketable yield of zucchini grown in the greenhouse and the threshold of SMP, so that the yield increased with the increasing soil moisture level. For the zucchini crop, Contreras et al. [3] determined that the decrease in the threshold of soil matrix potential from -10 to $-25 \mathrm{kPa}$ slightly affected the marketable yield, with a significant reduction of $10 \%$. However, the decrease to $-40 \mathrm{kPa}$ resulted in a reduction in the marketable yield of $23 \%$ with respect to $-10 \mathrm{kPa}$. In this experiment, the reduction in marketable yield was estimated at $17.7 \%$ when going from a threshold of between -15 and $-20 \mathrm{kPa}$ to another of between -25 to $-35 \mathrm{kPa}$. The effect of SMP on productivity has been studied by different authors in different crops and production systems [33-37]. Agreeing with observations of this experiment, some authors have observed a relationship between the SMP and yield of the crops, finding that with lower SMP, crop yield was reduced. Specifically, Zheng et al. [35] found that the decrease in soil matric potential from $-10 \mathrm{kPa}$ to $-50 \mathrm{kPa}$ reduced tomato production between $23.0 \%$ and $27.7 \%$ depending on the season, and Buttaro et al. [37] established that the tomato irrigated at the potential of $-40 \mathrm{kPa}$ showed a $40 \%$ lower yield (mainly due to the lower fruit size) compared to that of plants irrigated at $-10 \mathrm{kPa}$. Létourneau et al. [36] improved yields of strawberry crops (6.2\%) with a soil matric potential of $-15 \mathrm{kPa}$ to $-20 \mathrm{kPa}$. However, the results obtained in this study are in disagreement with the results obtained by Bonachela et al. [38] who affirm that fruit-vegetable greenhouse crops can be irrigated under a relatively wide range of SMP values without significantly affecting their yields. This statement would be valid in the context that these authors study (experiments are not fully comparable), since they apply the same volume of irrigation water in all treatments (in the treatment of high availability of water in the soil and in the treatment of low availability of water in the soil) considering that the high or low availability of water in the soil is associated with the SMP before irrigation. For this, these authors varied the irrigation frequency and rate of irrigation depending on treatment to obtain different SMP values before irrigation; however, the average SMP would possibly be the same in the two treatments, and for this reason they would obtain the same production between treatments, but this hypothesis could not be demonstrated because it did not present the daily evolution or the daily amplitude of the SMP.

On the other hand, and coinciding with our results, conserving a SMP closer to zero (that is, a higher level of soil humidity and a greater availability of water) implies the application of a greater volume of irrigation water, as derived from numerous works [3,33-37]. The total volume of irrigation water necessary to maintain the SMP threshold between -15 and $-20 \mathrm{kPa}$ during the whole cycle of the zucchini crop was $376 \mathrm{~L} \mathrm{~m}^{-2}$ (FV100\% level). The reduction in this volume by $30 \%$ (FV70\%) supported the application of $272 \mathrm{~L} \mathrm{~m}^{-2}$, a volume similar to that estimated according to ETc with average climate data and using the methodology proposed by Fernandez et al. [17] but limited crop productivity under our development conditions.

In addition, the reduction in the application of the volume of water and nutrients applied in irrigation (fertigation) produced a lesser development of the plant, and although the aerial dry biomass was not significantly affected, the fresh aerial biomass and the percentage of dry material of leaves and fruits were affected. The increase in the percentage of the dry leaf and fruit material registered in the FV70\% treatment, as well as the reduction in fresh aerial biomass are indicators that confirm that this treatment was deficient in the supply of water. Coinciding with numerous investigations $[3,33,34,37]$, 
deficit irrigation produces an increase in the percentage of dry material in the aerial tissues, as well as a reduction in vegetative growth.

WUE and nutrient use efficiency were also modified by FV levels. The greatest WUE and nutrient use efficiency was achieved by FV70\% and FV100\% level reduced values of efficiencies. The results obtained in this study were consistent with numerous investigations where the WUE is related to the soil matric potential, and a greater potential causes a lower efficiency [36,37]. Moreover, the yield is also associated with the matric potential of soil in an inverse relationship to the WUE, greater potential increased fruit production [35-37].

\section{Conclusions}

Under the conditions of development of the trial, both the level of distribution uniformity and the level of fertigation applied had an influence on the bio-productivity and on the efficiency of use of water and nutrients in the production of zucchini.

The maximum efficiency in the use of water and nutrients was obtained with a DU of $100 \%$ or $75 \%$ and a fertigation volume of FV70\%, but this fertigation volume reduced the bio-productive parameters of the crop such as yield.

The maximum yield and biomass were obtained with the volume of fertigation of $100 \%$ (FV100\%), and with a DU of $100 \%$ or $75 \%$.

The DU50\% level reduced all bio-productive parameters, reducing yield by $45 \%$, as well as the WUE and nutrient efficiency in a similar way with any level of fertigation.

Author Contributions: Conceptualization and methodology, J.I.C., R.B. and D.L.; validation, formal analysis, investigation, resources and data curation, J.I.C. and R.B.; writing-original draft preparation, J.I.C.; writing-review and editing, J.I.C. and R.B.; supervision, R.B.; project administration, D.L.; funding acquisition, D.L. data acquisition, validation and supervision, J.I.C., R.B., F.A., G.C., P.G. and D.L. All authors have read and agreed to the published version of the manuscript.

Funding: This research was funded by the project "Gestión sostenible del regadío en la agricultura intensiva de Andalucía". (RTA2015-00029-C02) financed by INIA and FEDER 2014-2020 ("Programa Operativo de Crecimiento Inteligente") and by the European Regional Development Fund (ERDF), grant number A1122062U0, and the Agricultural Research and Training Institute of Andalusia (IFAPA), under project: Technological Transfer for an Irrigation Sustainable. SAR, with code PP.TRA.TRA2019.006. The APC was funded by IFAPA.

Acknowledgments: We would like to thank Nicholas Andrew Davies for the English language correction. David Lozano is grateful for the financing of his contract to the "Subprograma de Incorporación del Programa Estatal de Promoción del Talento y su Empleabilidad del Plan Estatal de Investigación Científica y Técnica y de Innovación 2013-2016 (DOC-INIA)", co-financed by INIA and for the European Social Fund (FSE).

Conflicts of Interest: The authors declare no conflict of interest.

\section{Abbreviations}

The following abbreviations are used in this manuscript:

DU Uniformity Distribution Coefficient

FV Fertigation Volume

WUE Water Use Efficiency

NUE Nitrogen Use Efficiency

PUE Phosphorus Use Efficiency

KUE Potassium Use Efficiency

CaUE Calcium Use Efficiency

MgUE Magnesium Use Efficiency

HI Harvest Index

DB Dry Biomass

DM Dry Matter 


\section{References}

1. UNESCO. The Agenda 21 World Water Development Report 3: Water in a Changing World; World Water Assessment Programme; UNESCO: Paris, France, 2009.

2. Evans, R.G. Microirrigacion; 24106 North Bunn Roas Prosser; Washington State University, Irrigated Agriculture Research and Extension Center: Washington, DC, USA, 2002.

3. Contreras, J.I.; Alonso, F.; Cánovas, G.; Baeza, R. Irrigation management of greenhouse zucchini with different soil matric potential level. Agronomic and environmental effects. Agric. Water Manag. 2017, 183, $26-34$. [CrossRef]

4. Garcia-Caparros, P.; Contreras, J.I.; Baeza, R.; Segura, M.L.; Lao, M.T. Integral management of irrigation water in intensive horticultural systems of Almería. Sustainability 2017, 9, 2271. [CrossRef]

5. Nederhoff, E.; Stanghellini, C. Water Use Efficiency of Tomatoes. Pract. Hydroponics Greenh. 2010, 115, 52.

6. Baeza, R.; Gavilán, P.; Del Castillo, N.; Berenguel, P.; López, J.G. Programa de evaluación y asesoramiento en instalaciones de riego en invernadero con uso de dos fuentes distintas de agua: Subterránea y regenerada. In Proceedings of the XXVIII Congreso Nacional de Riegos, León, Spain, 15-17 June 2010; pp. 111-112.

7. Baeza, R.; Cánovas, G.; Alonso, F.; Contreras, J.I. Evaluación de las instalaciones de riego en cultivos hortícolas intensivos del sureste de Andalucía. In El Agua en Andalucía. El agua, Clave Medioambiental y Socioeconómica; Tomo II; SIAGA; Instituto Geológico y Minero de España: Málaga, Spain, 2015.

8. Baeza, R.; Contreras, J.I. Evaluation of Thirty-Eight Models of Drippers Using Reclaimed Water: Effect on Distribution Uniformity and Emitter Clogging. Water 2020, 12, 1463. [CrossRef]

9. Lozano, D.; Ruiz, N.; Gavilán, P. Efecto de la Pendiente en la Calidad de un Riego Localizado. Formato digital (e-book). In Consejería de Agricultura, Pesca y Desarrollo Rural; Instituto de Investigación y Formación Agraria y Pesquera (Junta de Andalucia): Córdoba, Spain, 2018; pp. 1-20.

10. Gavilán, P.; Ruiz, N.; Lozano, D. Innovación y cambio tecnológico en los sistemas agrarios intensivos mediterráneos. In El Regadío en el Mediterráneo Español. Una Aproximación Multidimensional, 1st ed.; Garrido, A., Pérez-Pastor, A., Eds.; Cajamar- Caja: Rural, Spain, 2019; Volume 38, pp. 181-206.

11. Guan, H.; Li, J.; Li, Y. Effects of drip system uniformity and irrigation amount on cotton yield and quality under arid conditions. Agric. Water Manag. 2013, 124, 37-51. [CrossRef]

12. Wang, Z.; Li, J.; Li, Y. Effects of drip system uniformity and nitrogen application rate on yield and nitrogen balance of spring maize in the North China. Plain. Field Crops Res. 2014, 159, 10-20. [CrossRef]

13. Pérez-Ortolá, M.; Daccache, A.; Hess, T.M.; Knox, J.W. Simulating impacts of irrigation heterogeneity on onion (Allium cepa L.) yield in a humid climate. Irrig. Sci. 2015, 33, 1-14.

14. Mateos, L.; Mantovani, E.C.; Villalobos, F.J. Cotton response to non-uniformity of conventional sprinkler irrigation. Irrig. Sci. 1997, 17, 47-52. [CrossRef]

15. Bordovsky, J.P.; Porter, D.O. Effect of subsurface drip irrigation system uniformity on cotton production in the Texas High Plains. Appl. Eng. Agric. 2008, 24, 465-472. [CrossRef]

16. Zhao, W.; Li, J.; Li, Y.; Yin, J. Effects of drip system uniformity on yield and quality of Chinese cabbage heads. Agric. Water Manag. 2012, 110, 118-128. [CrossRef]

17. Fernández, M.D.; Orgaz, F.; Fereres, E.; López, J.C.; Céspedes, A.; Pérez, J.; Bonachela, S.; Gallardo, M. Programación del Riego de Cultivos Hortícolas bajo Invernadero en el Sudeste Español; Cajamar (Caja Rural Intermediterránea): Almería, Spain, 2001.

18. Gavilán, P.; Estévez, J.; Berengena, J. Comparison of standardized reference evapotranspiration equations in Southern Spain. J. Irrig. Drain. Eng. 2008, 134, 1-12. [CrossRef]

19. Fernández, M.D.; Bonachela, S.; Orgaz, F.; Thompson, R.; López, J.C.; Granados, M.R.; Gallardo, M.; Fereres, E. Measurement and estimation of plastic greenhouse reference evapotranspiration in a Mediterranean climate. Irrig. Sci. 2010, 28, 497-509. [CrossRef]

20. González-Esquiva, J.M.; Oates, M.J.; García-Mateos, G.; Moros-Valle, B.; Molina-Martínez, J.M.; Ruiz-Canales, A. Development of a visual monitoring system for water balance estimation of horticultural crops using low cost cameras. Comput. Electron. Agric. 2017, 141, 15-26. [CrossRef]

21. Observatorio de Precios y Mercados. Junta de Andalucia. Datos Basicos de Producto de Calabacín. Campaña 2018/19. Available online: https:/www.juntadeandalucia.es/agriculturaypesca/observatorio/ servlet/FrontController?action $=$ List $\&$ table $=11113 \&$ subsector $=20 \&$ page $=1 \& e c=$ default $\quad($ accessed $\quad$ on 9 July 2020). 
22. Contreras, J.I.; Martín, F.; Zapata, A.J.; López, J.G.; Baeza, R. Caracterización de suelos enarenados para la producción de pimiento en invernadero en la comarca del Campo de Dalías (Almería). In Proceedings of the XXXII Congreso Nacional de Riegos, Madrid, Spain, 10-12 June 2014; pp. 1-8.

23. Keller, J.; Karmeli, D. Trickle irrigation design parameters. Trans. ASAE 1974, 17, 678-0684. [CrossRef]

24. Allen, R.G.; Pereira, L.S.; Raes, D.; Smith, M. Crop Evapotranspiration: Guidelines for Computing Crop Water Requirements; Food and Agriculture Organization of the United Nations: Rome, Italy, 1998.

25. Camacho, F.F.; Fernández, E. Manual Práctico de Fertirrigación en Riego por Goteo; Ediciones Agrotécnicas: Madrid, Spain, 2008.

26. Kang, S.; Zhang, J. Controlled alternate partial root-zone irrigation: Its physiological consequences and impact on water use efficiency. J. Exp. Bot. 2004, 55, 2437-2446. [CrossRef] [PubMed]

27. Wang, D.; Kang, Y.; Wan, S. Effect of soil matric potential on tomato yield and water use under drip irrigation condition. Agric. Water Manag. 2007, 87, 180-186. [CrossRef]

28. Fageria, N.K.; Baligar, V.C. Enhancing nitrogen use efficiency in crop plants. Adv. Agron. 2005, 88, 97-185.

29. Van Eerd, L.L. Evaluation of different nitrogen use efficiency indices using field-grown green bell peppers (Capsicum annuum L.). Can. J. Plant Sci. 2007, 87, 565-569.

30. Yasuor, H.; Ben-Gal, A.; Yermiyahu, U.; Beit-Yannai, E.; Cohen, S. Nitrogen management of greenhouse pepper production: Agronomic, nutritional, and environmental implications. HortScience 2013, 48, 1241-1249. [CrossRef]

31. FAO. Crop water requirements. In Irrigation and Drainage Paper No. 24; FAO: Rome, Italy, 1982.

32. Wang, J.; Li, J.; Guan, H. Evaluation of Drip Irrigation System Uniformity on Cotton Yield in an Arid Region using a Two-Dimensional Soil Water Transport and Crop Growth Coupling Model. Irrig. Drain. 2017, 66, 351-364. [CrossRef]

33. Liu, H.; Yang, H.; Zheng, J.; Jia, D.; Wang, J.; Li, Y.; Huang, G. Irrigation scheduling strategies based on soil matric potential on yield and fruit quality of mulched-drip irrigated chili pepper in Northwest China. Agric. Water Manag. 2012, 115, 232-241. [CrossRef]

34. Jia, J.; Kang, Y.; Wan, S. Effect of soil matric potential on wolfberry (Lycium barbarbum L.) yield, evapotranspiration and water use efficiency under drip irrigation. Afr. J. Agric. Res. 2013, 8, 5455-5463.

35. Zheng, J.; Huang, G.; Jia, D.; Wang, J.; Mota, M.; Pereira, L.S.; Huang, Q.; Liu, H. Responses of drip irrigated tomato (Solanum lycopersicum L.) yield, quality and water productivity to various soil matric potential thresholds in an arid region of Northwest China. Agric. Water Manag. 2013, 129, 181-193. [CrossRef]

36. Létourneau, G.; Caron, J.; Anderson, L.; Cormier, J. Matric potential-based irrigation management of field-grown strawberry: Effects on yield and water use efficiency. Agric. Water Manag. 2015, 161, 102-113. [CrossRef]

37. Buttaro, D.; Santamaria, P.; Signore, A.; Cantore, V.; Boari, F.; Montesano, F.F.; Parente, A. Irrigation Management of Greenhouse Tomato and Cucumber Using Tensiometer: Effects on Yield, Quality and Water Use. Agric. Agric. Sci. Procedia 2015, 4, 440-444. [CrossRef]

38. Bonachela, S.; González, A.M.; Fernández, M.D.; Cabrera-Corral, F.J. Vegetable Crops Grown under High Soil Water Availability in Mediterranean Greenhouses. Water 2020, 12, 1110. [CrossRef]

(C) 2020 by the authors. Licensee MDPI, Basel, Switzerland. This article is an open access article distributed under the terms and conditions of the Creative Commons Attribution (CC BY) license (http://creativecommons.org/licenses/by/4.0/). 